\title{
Possible Role of Plant Allelochemical in Clearance of Bacteria from the Gut of Spruce Budworm, Choristoneura fumiferana
}

\author{
Anthony S.D. Pang* \\ Great Lakes Forestry Centre, CFS, NRCan, 1219 Queen Street East, Sault Ste. Marie, Ontario, Canada P6A 2E5, Canada
}

\begin{abstract}
Field results, using Bacillus thuringiensis delta-endotoxin in controlling spruce budworms, Choristoneura fumiferana, are far less satisfactory than those from the laboratories

The role of septicemia has also been shown to be important in mortality. However its relationship with insect diet has not been studied. Insect gut juice from spruce budworm fed on balsam foliage inhibited bacterial growth. Such activity has not been observed in the gut juice from insects fed on artificial diet. Moreover, when bacteria were given to the insects orally, and the insects then fed on balsam foliage overnight, little or no bacterial colonies could be detected in their gut juices in the tryptic soy agar plates. Such bacterial growth inhibition activity could also be found in the water extract of balsam foliage, and was suggested to be due to tannins. This result explains the role of allelochemicals affecting septicemia in spruce budworms, and hence the efficacy, when using Bacillus thuringinesis delta-endotoxin as a biologic control agent.
\end{abstract}

Keywords: Spruce budworm, Choristoneura fumiferana, bacteriostatic, gut juice, tannins.

\section{INTRODUCTION}

Spruce budworm, Choristoneura fumiferana, is a forest pest in Eastern Canada. Biologic control agents, Bacillus thuringinesis $\delta$-endotoxin and viruses, have been developed and used in controlling this forest pest. However, field results are far less satisfactory than those from the laboratories $[1,2]$. Though there are many factors affecting the field results, e.g., size of droplets, temperature, wind speed, sunlight etc. little attention has been paid to the insect diets.

In the laboratory, spruce budworms are raised on artificial diet containing antibiotics. The natural diet of spruce budworms is foliage which contains many allelochemicals. These allelochemicals may affect the efficacy of biologic insecticides. Lüthy et al. [3] showed that tannins from plants inactivate $B$. thuringinesis $\delta$-endotoxin, and suggested that interaction between host plant tannins and B. thuringinesis $\delta$ endotoxin might be a major factor where the field efficacy of $B$. thuringinesis preparations is unexpectedly low. Bacterial septicemia also appears to play a very important role in the mortality of spruce budworm larvae [4]. In this study, we investigated whether gut contents of the insects, reared in different diets, would affect the growth of the bacteria in the insect guts.

\section{MATERIALS AND METHODS}

\section{Insects}

Spruce budworms were usually raised in artificial diet containing aureomycin from $1^{\text {st }}$ to $5^{\text {th }}$ instar in this Centre.

*Address correspondence to this author at the Great Lakes Forestry Centre, CFS, NRCan, 1219 Queen Street East, Sault Ste. Marie, Ontario, Canada P6A 2E5, Canada; Fax: 705-759-5700;

E-mail: Anthony.Pang@NRCan-RNCan.gc.ca
First day $6^{\text {th }}$ instar insects were then divided into two populations. One population was fed on artificial diet without antibiotics, while the other fed on balsam foliage. After three days, their gut juice and hemolymph were collected.

\section{Collection of Insect Gut Juice and Hemolymph}

Insect gut juice was collected by placing a Pasteur pipette to its mouth while squeezing its body gently. Insect hemolymph was collected into a microtube with a few grains of phenylthiourea, to prevent melanization, by punching a hole to its body with a hypodermic needle. Both gut juice and hemolymph samples were centrifuged and the clear supernatant was either used immediately or stored at $-80^{\circ} \mathrm{C}$ until use.

\section{Bacterial Strains}

E. coli wild strain EmG31, P. aeruginosa insect strain P11-1 and B. cereus were obtained from Dr. J. Chadwick, Department of Microbiology and Immunology, Queen's University, Kingston, Ontario, Canada. B. thuringinesis strain HD-76 was from a collection at GLFC. Bacteria were grown in tryptic soy broth for $24 \mathrm{hrs}$ before use.

\section{Extraction of Balsam Foliage and Insect Frass}

Balsam foliage was freeze-dried overnight and ground into powder using a blender. One volume of foliage was suspended into 10 volumes of distilled water. The suspension was either boiled in a water bath for 30 min or soaked with shaking at RT overnight. Frass from insects was collected and soaked in 4 volumes of distilled water overnight at $4^{0} \mathrm{C}$. All the suspensions were then centrifuged and filtered with a $0.22 \mu \mathrm{m}$ filter. The clear filtrates were either used immediately or stored at $-80^{\circ} \mathrm{C}$ before use. 


\section{Antibacterial Assays}

\section{Radial Diffusion Growth Inhibition Assay}

One to $4 \times 10^{6} \mathrm{CFU}$ of bacteria suspended in $10 \mathrm{ml}$ of tryptic soy agar $(4 \%)$ at $50^{\circ} \mathrm{C}$ was poured into a petri dish. After the agar had set, wells with a diameter of $3 \mathrm{~mm}$ were made using a gel puncher. Six $\mu l$ of sample or control was added to the wells. The plates were then incubated at RT $\left(26^{\circ} \mathrm{C}\right)$ for three hrs to allow samples to diffuse radially into the agar. The plates were then incubated at $37^{\circ} \mathrm{C}$ overnight. Inhibition of bacterial growth was indicated by a clear ring around the well. To enhance the results, the gels were stained for $24 \mathrm{hr}$ in a dilute solution of Coomassie brilliant blue R-250 (dye: $2 \mathrm{mg}$, methanol:27 ml, water: $63 \mathrm{ml}, 37 \%$ formaldehyde: $15 \mathrm{ml}$ ), and then washed with $10 \%$ acetic acid containing 2\% dimethylsuphoxide for 10 minutes [5].

\section{Micro-Culture Assay}

Fifty $\mu 1$ of insect gut juice or sample was added to $25 \mu 1$ of a $10^{-5}$ dilution of an overnight culture of bacterium in a 96-well microtiter plate. The diluent was $20 \%$ tryptic soy broth in $0.85 \%$ saline. The mixtures were incubated at RT for $30 \mathrm{~min}$. Two hundred $\mu \mathrm{l}$ of tryptic soy broth were added to each well, and the plate was incubated at $37^{\circ} \mathrm{C}$ overnight. The plate was then read at $\mathrm{OD}_{600 \mathrm{~nm}}$ using an ELISA scanner (Elx-808, Bio-Tek Instrument).

\section{Detection of Bacteria in Insect Gut Juice}

Sixth instar spruce budworms, which had been fed on either antibiotic-free artificial diet or balsam foliage for three days, were used in this experiment. Two $\mu \mathrm{l}$ of $E$. coli suspension containing about $5 \times 10^{4} \mathrm{CFU}$ were force-fed into the insects. The insects were then allowed to continue to feed on their respective diets overnight. Insects gut juices were collected and $100 \mu \mathrm{l}$ of diluted gut juice (1:10 with sterile PBS) were plated in a tryptic soy agar plate. Bacterial colonies on the agar plate were then counted after $24 \mathrm{hr}$ incubation at $37^{0} \mathrm{C}$

\section{Paper Chromatography}

Strips of $1 \frac{1}{2} \mathrm{~cm}$ wide Whatman No.2 filter paper were cut. Five hundred $\mu \mathrm{l}$ samples of insect gut juice fed on Balsm folige, commercial tannins (Sigma Chemicals) and water extract of balsm foliage were applied to about $5 \mathrm{~cm}$ to one end. They were then suspended vertically in a 2 litre measuring cylinder. The cylinder contained enough distilled water to wet about $2 \mathrm{~cm}$ of the filter paper strips. The cylinder was then covered with tin foil, and the water was allowed to run against gravity until the water front reached about $5 \mathrm{~cm}$ from the top. The filter paper was cut into small pieces of about 1 $\mathrm{cm}$ long. These small pieces of filter strips were then placed on tryptic soy agar plates containing $E$. coli. Inhibition of bacterial growth surrounding the filter paper was observed after $16 \mathrm{hr}$ incubation at $37^{\circ} \mathrm{C}$.

\section{RESULTS AND DISCUSSION}

\section{Antibacterial Activity}

Fig. (1) shows that gut juice obtained from spruce budworm fed on artificial diet (well A) had little bacterial growth inhibition. In contrast, gut juice from insects fed on balsam foliage for three days showed very strong bacteria growth inhibition (well C). Since the $\mathrm{pH}$ in both gut juices was the same ( $\mathrm{pH} 10)$, the bacterial growth inhibition was not due to the high $\mathrm{pH}$ of the gut juice. No inhibition was observed in either hemolymph (well $\mathbf{G}$ and $\mathbf{F}$ ), suggesting that the bacterial growth inhibition factor(s) were restricted within the gut and would not pass into the hemocoel. Frass extract from insects fed on foliage (Well E) and water extracts of balsam foliage exhibited similar bacterial growth inhibition (wells $\mathbf{B}$ and D).

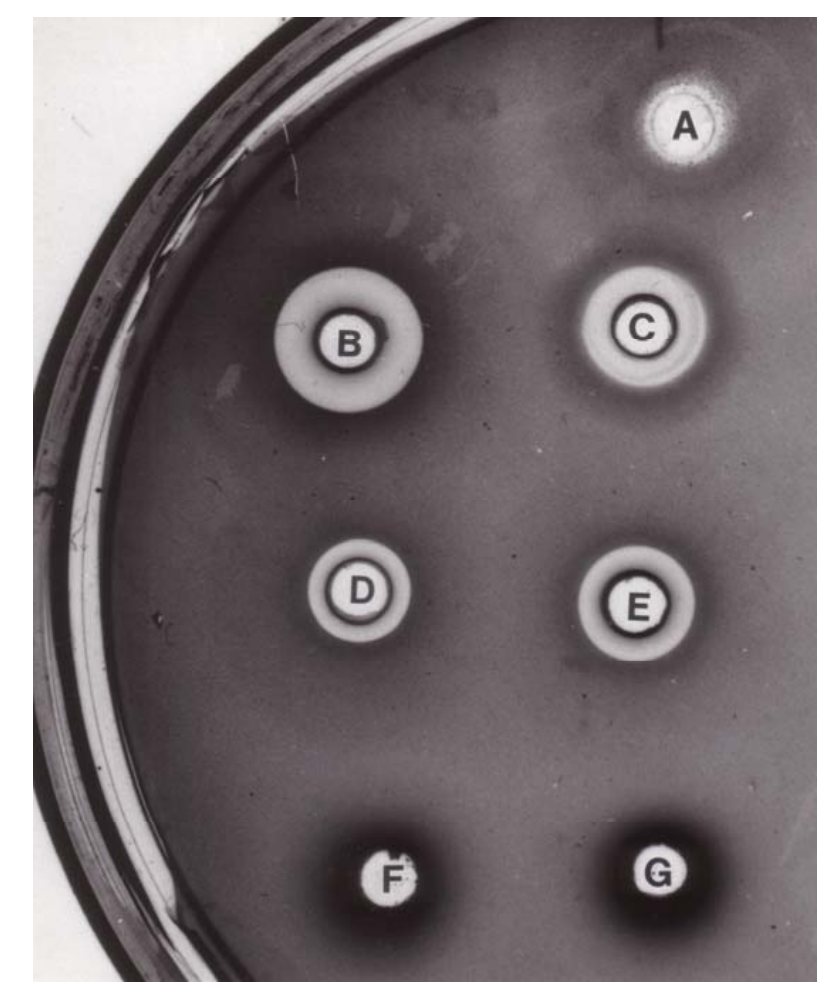

Fig. (1). Radial diffusion growth inhibition assay. Tryptic soy agar plate contained about $4 \times 10^{6}$ E. coli. Six $\mu 1$ of sample was applied to the wells. The plate was incubated at RT to allow the sample to diffuse radially into the agar, and then incubated at $37^{\circ} \mathrm{C}$ overnight. Bacterial growth inhibition was indicated by clear area surrounding the well. A: spruce budworm (artificial diet) gut juice, B: balsam foliage water extract, $\mathbf{C}$ : spruce budworm (foliage diet) gut juice, $\mathbf{D}$ : balsam foliage water extract boiled for $30 \mathrm{~min}$, E: spruce budworm (foliage diet) frass water extract, $\mathbf{F}$ : spruce budworm (artificial diet) hemolymph, G: spruce budworm (foliage diet) hemolymph.

In the micro-culture assay, it gave similar results. Culture media in those wells containing bacteria and gut juice from insects fed with foliage were completely clear, suggesting no bacterial growth. Heavy bacterial growth was observed in both hemolymph and gut juice from insects fed on artificial diet.

Table 1 shows a list of bacteria tested. The bacteria growth inhibition was non-specific, and gut juice from spruce budworms fed on balsam foliage showed the greatest inhibition.

\section{Detection of Bacteria in Insect Gut Juice}

First day $6^{\text {th }}$ instar spruce budworms were raised on either artificial diet or balsam foliage for three days, and were 
Table 1. Summary of Bacterial Growth Inhibition

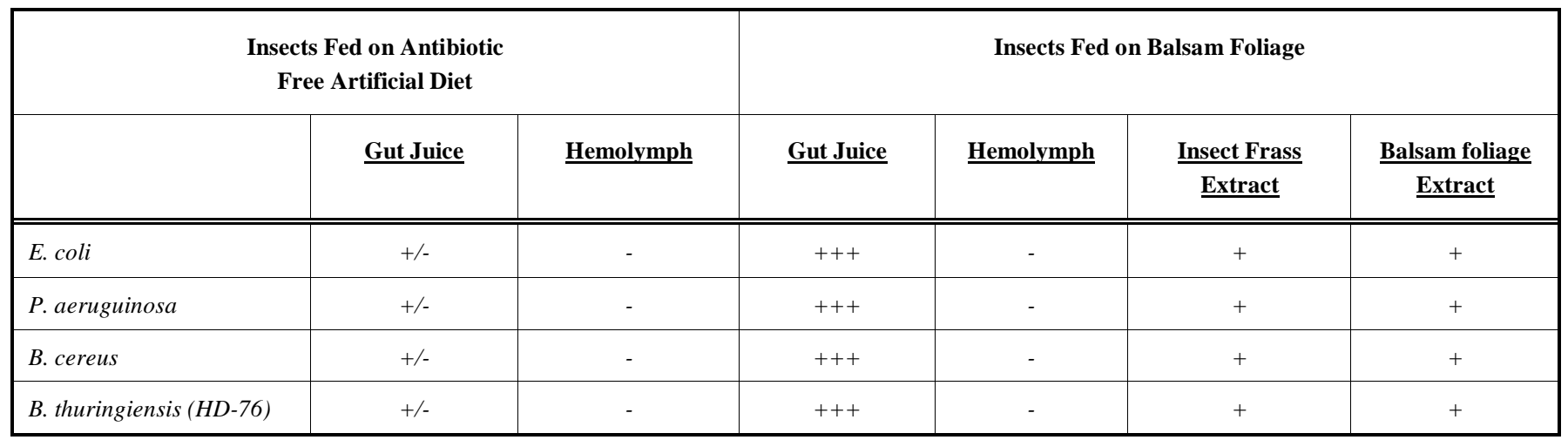

- no growth inhibition $(\mathrm{OD}=3 \mathrm{~mm}$ size of the gel punch) + - Little or marginal growth inhibition $(3 \mathrm{~mm}<\mathrm{OD}>5 \mathrm{~mm})$; + strong growth inhibition $(5 \mathrm{~mm}<\mathrm{OD}>10 \mathrm{~mm})$; ++strong growth inhibition $(10 \mathrm{~mm}<\mathrm{OD}>12 \mathrm{~mm}$; +++ very strong growth inhibition $(12 \mathrm{~mm}<\mathrm{OD})$.

then force-fed with $2 \mu 1$ of $5 \times 10^{4} \mathrm{E}$. coli. The insects were then fed on their respective diets. After $24 \mathrm{hr}$, insect gut juices were collected and $100 \mu 1$ of diluted gut juice were plated in the tryptic soy agar plates. Very few bacterial colonies (under 10) were observed in the gut juice of those insects fed on balsam foliage. However, $143( \pm 30)$ bacterial colonies were observed in the gut juice from insects fed on artificial diet. This suggests that most of the bacteria in the insect guts were cleared when they fed on balsam foliage but not on artificial diet after $24 \mathrm{hr}$.

Since the bacterial growth inhibition in the insect gut juice and the clearance of bacteria in their guts are related to its diet, it is likely that allelochemicals from the balsam foliage may be the contributor for such properties.

\section{Some Properties and Possible Identification of the Anti- bacterial Component(s)}

\section{The Effect of pH and BSA on the Antibacterial Activity of the Foliage Extract}

The $\mathrm{pH}$ of the balsam foliage water extract was about 5 , and the insect gut juice (either on artificial diet or foliage) is about 10.2. To determine whether the bacteria growth inhibition in the balsam foliage extract is due to $\mathrm{pH}$, the water extract was adjusted to a different $\mathrm{pH}$. Fig. (2) shows that water extract of balsam foliage at $\mathrm{pH} 5$ gave the best bacterial growth inhibition. Its ability to inhibit bacteria growth decreased as its $\mathrm{pH}$ increased to 10 (Fig. 2 Upper row). Phosphate saline at $\mathrm{pH} 5$ and 10 would not inhibit bacteria growth (not shown). The color of the extract also changed from light green to reddish brown as its $\mathrm{pH}$ was adjusted from 5 to 10 . The color of the spruce budworm gut juice fed on balsam foliage is reddish brown with $\mathrm{pH}$ about 10.2

The bacterial growth inhibition ability of balsam foliage extracts, though heat stable (Fig 1, well D), was further reduced when excess BSA was added to the extracts (Fig. 2 Lower row). This result suggests that bacterial growth inhibition is probably due to some protein precipitating allelochemical(s) present in the balsam foliage.

Because the color of the balsam foliage extract changes to red when its $\mathrm{pH}$ was adjusted to 10 , and it precipitated BSA, it is suggested that the inhibition property in the balsam foliage extract is due to the presence of tannins. To confirm this, ferric salt was added to balsam foliage extract, gut juice and frass extract from foliage fed insects. All these three samples gave dark blue precipitate indicating the presence of tannins. On the other hand, gut juice from insects fed on artificial diet did not give blue color, indicating the absence of tannins.

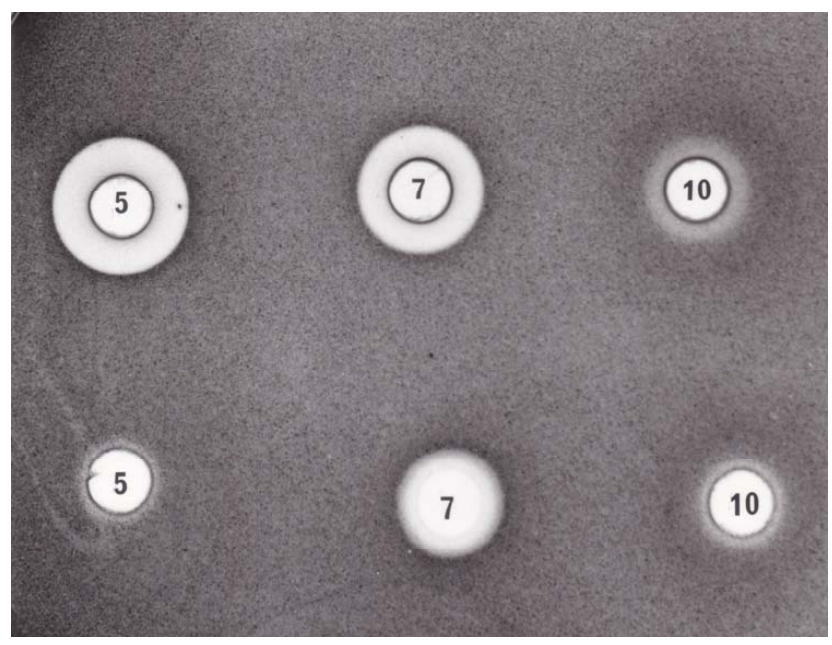

Fig. (2). Radial diffusion growth inhibition assay. Tryptic soy agar plate contained about $4 \times 10^{6} \mathrm{E}$. coli. The $\mathrm{pH}$ of the balsam foliage water extract was adjusted to 7 and 10 using $0.01 \mathrm{M} \mathrm{NaOH}$. Powder BSA was added to the foliage extract until no more precipitate was formed.Upper row: balsam foliage water extract at pH5, 7 and $\mathbf{1 0 .}$ Lower row: balsam foliage water extract saturated with BSA.

\section{Paper Chromatographies}

Gut juice from insects fed on balsam foliage, commercial tannic acid and water extract of balsam foliage (all at pH10.2) were applied to the filter papers for paper chromatography. Maximum bacterial growth inhibition appeared at approximately the same position for all three samples. This indicated that the inhibition factor(s) in the three samples are similar or identical.

The possible identification of tannins as the responsible agent for bacterial growth inhibition in the spruce budworm gut juice is summarized in Table 2. 
Table 2. Identification of the Bacterial Growth Inhibition Factor(s)

\begin{tabular}{|c|c|c|c|}
\hline & Gut Juice from Insect & Balsam Foliage & Commercial \\
\hline \hline$\underline{\text { Test }}$ & $\underline{\text { fed on balsam foliage }}$ & $\underline{\text { water extract }}$ & $\underline{\text { tannic acid }}^{*}$ \\
\hline BSA & precipitation & precipitation & precipitation \\
\hline $\begin{array}{c}\text { Fe } \\
\text { Paper } \\
\text { chromatography }\end{array}$ & $\begin{array}{r}\text { dirty dark blue ppt } \\
\text { Bacterial growth inhibition appeared at approximately the same position } \\
\text { in all three samples, and stained dark blue when Fe } \mathrm{F}^{+++} \text {was added. }\end{array}$ \\
\hline
\end{tabular}

* From Sigma Chemicals.

\section{Possible Role of Plant Tannins in Preventing Bacterial Infection and Biologic Insecticides}

One of the main differences between field and laboratory insects is their diets. Laboratory raised spruce budworm feed on artificial diet with addition of antibiotics. Field insects feed on foliage. Therefore the gut contents in both insect populations are quite different. It is expected that the fieldraised insect gut juice contains high concentrations of allelochemicals. Some of these allelochemicals may have effects on the bacteria in the insect gut. In this communication, we showed that gut juice from spruce budworm fed on foliage inhibited bacterial growth in a tryptic soy agar plate, and cleared bacteria from the insect gut. Though the allelochemi$\mathrm{cal}(\mathrm{s})$ responsible of such activity has not been isolated in this study, our experiments suggested that it belonged to tannins. However, it does not exclude other allelohemicals, and needs further identification.

B. thuringiensis is the most successful biological insecticide. When it is used in controlling forest pests, e.g., spruce budworm, the results are not consistent, and seldom match with those from the laboratory [1,2]. Lüthy et al. [3] showed that plant tannins would inactivate $B$ thuringiensis $\delta$ endotoxin. The high $\mathrm{pH}$ in the insect gut may have some effects on certain bacteria, however, it has been shown that $B$. thuringiensis spores would germinate at $\mathrm{pH} 10.0$ in the insect guts [6]. Septicemia also plays an important role in the efficacy of B. thuringiensis [4]. The present study shows that plant tannins would clear the bacteria from the insect guts, and inhibit their growth. All these may partially explain the lack of consistency of $B$. thuringiensis in the field trials.

Although the mechanisms by which tannins inhibit bacterial growth and clears bacteria from insect guts, is not yet known at this time, one would assume that plant tannins bind to the bacterial cells, thus preventing them from growing and adhering to the gut. These tannins-bound bacteria would then pass out of the insect gut with the frass. It is interesting to note that consumption of cranberry juice has been recom- mended for the prevention of urinary tract infection [7]. Recently, tannins have been identified as the compounds in cranberries that are responsible for preventing uropathogenic phenotypes of P-fimbriated E. coli from adhering to urinary tract [8]. Moreover, our preliminary in vitro study also showed that pre-treatment of $C f \mathrm{NPV}$ with balsam foliage extract reduces viral infection in insect cells (not shown).

Tannins are important constituents of many plants. The concentration of plant tannins in the insect guts would be expected to be the lowest as the insects coming out from their molts, or when their guts are empty. Based on this study, it is expected that biological insecticides, e.g. $B$. thuringiensis, would be most effective if they are applied at the time immediately following the molt.

\section{REFERENCES}

[1] Avorn J, Monane M, Gurwitz JH, Glynn RJ, Choodnovskiy I, Lipzitz LA. Reduction of bacteriuria and pyuria after ingestion of cranberry juice. JAMA 1994; 271: 751-4.

[2] Howell AB, Marderosian AD, Foo LY. Inhibition of the adherence of P- fimbriated $E$. coli to uroepithelial-cell surfaces by proanthocyanidin extracts from cranberries. N Engl J Med 1998; 339: $1085-6$

[3] Lehrer RI, Rosenman M, Harwig SSSL, Jackson R, Eisenhauer P. Ultrasensitive assays for endogenous antimicrobial polypeptides. J Immunol Methods 1991; 137: 167-73.

[4] Lüthy P, Hoffmann C, Jaquet F. Inactivation of delta-endotoxin of Bacillus thuringiensis by tannin. FEMS Microbiol Lett 1985; 28: 31-3.

[5] Morris ON. Report of the 1979 CANUSA cooperative Bacillus thuringiensis $(\mathrm{Bt})$ spray trials. Forest Pest Management Institute Report 1980; FPM-X-40: p.75.

[6] Morris ON. Report of the 1980 Cooperative Bacillus thuringiensis (Bt) spray trials. Forest Pest Management Institute Report 1981; FPM-X-48 pp. 74.

[7] van Frankenhuyzen K. Effect of temperature on the pathogenesis of Bacillus thuringiensis Berliner in larvae of the spruce budworm, Choristoneura fumiferana Clem. (Lepidoptera: tortricidae). Can Entomol 1994; 126:1061-5.

[8] Wilson GR, Benott TG. Activation and germination of Bacillus thuringiensis spores in Manduca sexta larval gut fluid. J Invert Pathol 1990; 56: 233-6. 